\section{Artigo recebido em:}

23.07.2016

Aprovado em:

03.08.2017

\section{Juliana Bulhões}

Doutoranda em Comunicação pela Universidade de Brasília (UnB); mestre em Estudos da Mídia pela

Universidade Federal do Rio Grande do Norte

(UFRN).

E-mail:

julianabulhoes.ad@ gmail.com

\section{Gustavo Leite Sobral}

Mestre em Estudos da Mídia pela Universidade Federal do Rio Grande do Norte (UFRN).

E-mail:

gustavosobral1041@ gmail.com.

\footnotetext{
${ }^{1}$ Uma versão deste texto foi apresentada no Encontro Nordeste de História da Mídia
} 2016.

\title{
Rachel de Queiroz, Jornalista ${ }^{1}$
}

\author{
Juliana Bulhões \\ Gustavo Leite Sobral
}

\section{Resumo}

Apesar de ter sido a primeira mulher a ingressar na Academia Brasileira de Letras e de ser popularmente reconhecida como escritora, Rachel de Queiroz (19102003) se definia como jornalista. Neste contexto, apresentamos um ensaio com viés biográfico acerca de sua trajetória neste ofício, enfatizando sua atuação na revista O Cruzeiro, na qual manteve a coluna semanal Última Página entre os anos de 1944 e 1975. Como parte da construção metodológica da pesquisa, fizemos um levantamento das crônicas nas quais a autora discorre sobre o fazer jornalístico e propomos algumas reflexões.

Palavra-chave: Gênero jornalístico. Rachel de Queiroz. Revista O Cruzeiro.

\begin{abstract}
Despite being the first woman to join Academia Brasileira de Letras and be popularly recognized as a writer, Rachel de Queiroz (1910-2003) defined herself as a journalist. We present an essay with biographical content about her career in this occupation, emphasizing her role in the magazine O Cruzeiro, in which she maintained the weekly column Última Página between the years 1944 and 1975. As part of the methodological construction of the research, we did a survey of the chronicles in which the author discusses journalism and we propose some reflections.
\end{abstract}

Keywords: Journalistic genre. Rachel de Queiroz. O Cruzeiro magazine. 
escritor e jornalista Graciliano Ramos acreditava que o autor de $O$ Quinze só poderia ser um homem utilizando o pseudônimo Rachel. O ano era 1930. O Quinze era um romance recém publicadoas custas do autor, coisa de mil exemplares, que marcou uma virada na literatura brasileira ao narrar em suas páginas o drama dos retirantes nordestinos fugindo das agruras da seca. Aquele romance, escrito à luz de lampião nas noites escuras da fazenda, alçaria a sua autora, que não era homem coisa nenhuma, era uma menina de vinte anos, chamada Rachel de Queiroz, ao cânone da literatura brasileira e depois a ser considerada protagonista de um movimento literário que ficou conhecido por Regionalismo.

Mulher, letrada, com incentivo dos pais para a leitura de jornais e livros, Rachel de Queiroz nasceu em Fortaleza, Ceará. O pai era promotor de justiça, portanto Rachel vinha de uma família abastada e pôde acompanhar o drama dos retirantes quando residia com a família em Fortaleza, durante a grande seca de 1915. Nesta história, não há diploma de jornalismo, porque faculdades para tal não existiam no Brasil, a primeira é fenômeno do final dos anos 1940, a Cásper Líbero, que foi fundada em 1947. Seu único diploma formal foi o do Curso Normal no Colégio Imaculada Conceição de Fortaleza.

Outra formação, conta a sua trajetória de vida e a biografia não escrita, é aquela que se espalha por declarações e depoimentos para reportagens e entrevistas (QUEIROZ, 1997). Depois de formada, se fez leitora dos grandes clássicos da literatura que devorara na vida que levava na fazenda, quando da mudança da família. Era a fazenda Junco de onde, futuramente, passando férias, enviaria a sua coluna semanal para a revista $O$ Cruzeiro.

Futuramente a menina Rachel colaboraria para a revista, numa longa permanênciaque vai de 1944 a 1975. Mas antes disso é preciso que se diga que começou, naquele tempo da moci- dade, no jornal O Ceará, no tempo em que era prática o uso de pseudônimos e o que escolheu no momento foi Rita de Queluz. Durante toda a sua vida, nas oportunidades que se apresentavam, gostava sempre de dizer que, mais que romancista e escritora, era jornalista. E assim os episódios narrados de sua vida sempre vão reforçar este pendão.

Conta a sua história que, escrevendo para o jornal e professora de história na mesma escola em que se diplomara, foi eleita rainha dos estudantes em um concurso promovido entre as aulas. A coroação com festa e pompa com direito a presença do governador do Estado foi interrompida por um fato e pelo exercício da vocação, naquele mesmo dia, João Pessoa era assassinado, episódio que mudaria a história do Brasil, pois a futura rainha segue às pressas da solenidade para a redação do jornal e sai com uma única justificativa: sou repórter.

Sua participação em O Ceará passa a ser perene e Rachel não só se encarrega de escrever um folhetim, que ganhou título de História de um nome, como também se encarregou de organizar uma página literária para o jornal. O destino mudaria um pouco as coisas, a suspeita de tuberculose a leva por recomendação médica a repouso na fazenda, foi aí que, à noite, quando todos dormiam, que ela, à luz do candeeiro, escreveria o primeiro romance.

No ano seguinte, 1931, já era premiada pela Fundação Graça Aranha do Rio de Janeiro. Começa então uma trajetória que a alça ao convívio das grandes personalidades do seu tempo, aproxima-se do partido comunista, rompe com o partido comunista que queria censurar seu romance, casa-se, mora em Maceió, São Paulo, se separa e definitivamente se muda para o Rio de Janeiro em 1939.

Casa-se pela segunda vez e começa a sua atividade jornalística nos jornais Correio da Manhã, O Jornal, Diário da Tarde e na revista semanal O Cruzeiro, na qual passa a assinar a coluna Última Página - chamada dessa forma por sempre figurar a última página de cada 
edição da revista -, e assim passa a exercer a profissão que considerou por toda vida como a sua, reiterando sempre que muito mais que escritora, era jornalista. O período de Rachel em O Cruzeiro começa em 1944 e vai até 1975.

Ressaltamos, assim, a trajetória de Rachel de Queiroz enquanto jornalista com ênfase na contribuição que perpassou quatro décadas na revista $\mathrm{O}$ Cruzeiro. Em seguida traçamos uma análise das crônicas publicadas na coluna Última Página nas quais a autora reflete sobre o fazer jornalístico.

\section{Rachel em O Cruzeiro}

São mais de trinta anos de colaboração na Revista O Cruzeiro, com uma interrupção apenas no ano de 1968, depois retomando em 1970. Onde quer que estivesse, em Fortaleza, na fazenda Junco, ou na Não me deixes (fazenda sua e de seu marido onde passava temporadas), em viagens, seja pelo Brasil, foi a Minas e sobre isso escreveu, ou Nova Iorque, onde esteve na função de delegada do Brasil na 21ํ Sessão da Assembleia Geral acompanhando os trabalhos da Organização das Nações Unidas, Rachel enviava a sua colaboração à revista $O$ Cruzeiro (JURY; SANTOS, 2016; MENDES, 2017).

Rachel classificou o seu texto de última página - que posteriormente reuniria em coletânea publicando em livro crônica (QUEIROZ, 2006). No entanto, no expediente da revista aparece como colaboradora e na divisão temática na seção "artigos". Importa considerar que, seja crônica, seja artigo, seja classificada cronista, articulista ou colaboradora, Rachel de Queiroz se considerava jornalista e foi jornalismo o que praticou.

Observar as suas publicações na revista $O$ Cruzeiro durante seu período de colaboração, que atravessa quatro décadas, revela que, além de sua coluna semanal, Rachel era personagem frequente em reportagens, notas, entrevistas e até como repórter especial registra-se colaboração sua. Rachel era uma intelectual e escritora respeitada com circula- ção nos meios sociais e políticos do Rio de Janeiro, inclusive chegou a receber convite do presidente Jânio Quadros, em 1961, para ocupar o Ministério da Educação. Ao declinar do convite, declarou inaptidão para o cargo alegando ser apenas jornalista e era o que gostaria de continuar sendo, e o foi, até o fim da vida. No entanto, a sua importância a fez membro do Conselho Federal de Cultura em 1967, permanecendo até 1985. Prêmios também revelariam a relevância da sua obra literária e reconhecimentos: em 1957, recebeu o Prêmio Machado de Assis da Academia Brasileira de Letras pelo conjunto de sua obra e em 1977 foi eleita imortal da mesma academia (QUEIROZ, 1997).

O Cruzeiro foi lançando em dezembro 1928, sem o "O" que seria acrescentado posteriormente. Cruzeiro era uma revista em papel de qualidade, com fotografias, colaboração de articulistas e escritores nacionais e estrangeiros, impressa em quatro cores pelo sistema rotogravura, semanal, com tiragem inicial de 50 mil exemplares e distribuição para todas as capitais e principais cidades do Brasil. Foi idealizada e criada pelo jornalista Assis Chateaubriand e fez parte da sua cadeia de comunicação que reunia diversos jornais impressos, emissoras de rádio e televisão, os Diários Associados.

Inicialmente a revista precisou ser confeccionada em Buenos Aires, Argentina, que dispunha de equipamentos gráficos avançados para o tipo de impressão necessária. A revista foi lançada com estardalhaço pelo jornalista que promoveu uma campanha jamais vista:

No final da tarde de 5 de dezembro, quando a avenida Rio Branco fervilhava de gente que deixava o trabalho ou saía às ruas para as primeiras compras do natal, $4 \mathrm{mi}$ lhões de folhetos - três vezes o número total de habitantes do Rio foram atirados do alto dos prédios sobre as cabeças dos passantes. Os volantes anunciavam o breve aparecimento de uma revista "contemporânea dos arranha-céus", 
uma revista semanal colorida que "tudo sabe, tudo vê"(MORAIS, 1994, p. 187).

Cinco dias depois, no dia 10 de dezembro de 1928, a revista estava nas bancas de todo país, que no editorial prometia ser uma revista de educação e cultura. A revista saiu com 64 páginas de conteúdo e anúncios, impressa em papel couchê, com fotografias, reportagens, entrevistas, artigos, contos e anúncios e se firmou como grande veículo nacional em poucos meses.

No ano seguinte, o jornalista Assis Chateaubriand já importava máquinas impressoras em quatro cores para imprimi-la no Brasil. A trajetória foi de ascensão, em 1929 já vendia 80 mil exemplares semanais. Ao longo de sua história, passou por mudanças na direção e reformas editoriais e gráfcas, inclusive por revezes motivados por crises políticas e econômicas. O Cruzeiro se tornou a revista de maior vendagem no país e uma revista de grandes reportagens com a chegada do repórter David Nasser e do fotógrafo Jean Mazon nos anos 1940:

Em um país com pouco mais de 40 milhões de habitantes (e uma taxa de analfabetismo que passava dos $30 \%$ ), estava vendendo quase 200 mil exemplares por semana. $\mathrm{Na}$ sua redação era possível ver desde jovens talentos, como Hélio Fernandes (...), Luis Barreto e Jorge Ferreira, até nomes mais experientes como o recém-contratado Samuel Wainer e Carlos Lacerda (...). Em um exemplar daquele ano de 1946, colhido ao acaso, é possível medir o dinamismo de O Cruzeiro; na mesma semana em que Wainer enviava reportagens especiais de Caracas sobre a exploração do território venezuelano, Carlos Lacerda escrevia de Paris sobre o bairro de Montmarte, e a dupla Nasser-Mazon mandava do Cairo matérias sobre arqueologia no Egito (MORAIS, 1994, p.472-473).
Na última página daquela edição, surgia Rachel de Queiroz. Rachel começa em O Cruzeiro como colaboradora, na coluna Última Página. Nela, semanalmente a jornalista escolhia um tema para apreciação compondo um mosaico variado de interesses e assuntos revelados que compreendem lembranças, impressões pessoais, viagens, aspectos relacionados a questões autobiográficas e memórias; respostas a cartas dos inúmeros leitores que lhe escreviam; comentários de fatos do cotidiano, comentários políticos e de questões em pauta no cenário nacional e internacional e o noticiário, em que Rachel revela de forma mais precisa a sua veia jornalística.

As crônicas de Rachel comentam o noticiário ao que parece ser uma forma reflexiva e crítica. A cronista narra o caso existente, seja cruel, dramático ou torpe, como o crime da menina do retrato, na crônica Retrato, de fevereiro de 1951. Rachel faz um uso particular e apropriase dos recursos da narrativa para expor o caso, começa de sua perspectiva, alega não gostar de tirar retratos, tece considerações de ordem geral, os retratos como instrumento da propaganda nazista e desce às raias de uma história comum, de personagens comuns que por uma banalidade da vida acabam envolvidos em um crime:

Não gosto de tirar retratos. Ou são instantâneos de amador e nos pegam desprevenidos sempre no momento pior de todos; ou são retratos de estúdio, sofisticados, retocados, espiritualizados, que a gente acaba se envergonhando de mostrar aos amigos, de tal modo eles nos traem, revelando-nos antes como sonháramos ser do que como somos.

Ademais, desde o nascimento do fascismo até hoje, retratos se transformam em arma política, e usar retrato de alguém ficou sendo a mesma coisa que usar braçadeira (...).

Assim pois não é de admirar que esses meninos nascidos apôs o 
quatriênio de Washington Luís, em vez de nossas idiossincrasias, sintam antes uma fé danada no poder da sugestão da imagem impressa. Tem que acreditar em tudo lhes ensina a propaganda - acreditam em horas do Brasil, em salvador, em policial especial e, claro, acreditam na influência mágica dos retratos distribuídos às dúzias. A menina da rua paralela à minha, por exemplo. Foi a um fotógrafo da rua Larga (...) pois a pequena foi nesse fotógrafo, bateu uma chapa igual a certa pose de Lana Turner (...).

Mandou reproduzir duas dúzias de fotos e dai danou-se a distribuí-la com tal afã que não perdia para um candidato a vereador (...).

Mas acontece que o progresso neste mundo sempre caminha a passo desigual: quando uns vão adiante, os demais ainda se arrastam lá atrás. (...) Assim, se a menina acreditava em retrato somente como fator de publicidade pessoal e, distribuindo-os, supunha que estava fazendo anúncio de si própria, o mesmo não pensavam dois rapazes da rua: esses ainda eram do tempo em que moça só dá retrato como sinal de muito amor. E como prova de amor particular e único receberam os seus exemplares e colocaram na carteira, por baixo da folha de celofane que os fabricantes põem nas carteiras justamente para este fim.

Como os dois chegaram a confrontar as carteiras, não se sabe direito (...). O fato é que o outro achou ruim, mostrou o seu retrato e também acabaram ambos se engalfinhando. (...) Sei que um furou o outro com canivete (...) e foi esperar a pequena na cerca da casa dela - a garota fora ao cinema com as amiguinhas. Com o mesmo canivete feriu-a também; queria pegar no coração, mas a mão resvalou, ou doeu-se de cortar o seio tão belo, e só feriu os braços e as coste-

\section{las. Quase só deu para o susto (...)} (QUEIROZ, 2006, p.187-189).

Esta passagem que revela o limiar entre jornalismo e literatura. Para Marques (2009) "produzir textos narrativos, ou seja, que contêm uma sequência de eventos que se sucedem no tempo, é algo que inclui tanto a vivência literária quanto a jornalística" (MARQUES, 2009, p. 14). Segundo o autor, o que vai definir se uma narrativa pertence ao gênero literário ou ao jornalístico é o contexto.

Há gêneros jornalísticos que permitem uma abertura maior a técnicas literárias, como o perfil de personalidades e reportagens investigativas. Há, também, editorias com a mesma característica, como a de cultura. Tudo vai depender, afinal, de como nos aproximamos de um determinado texto. Isso não impede que o autor lance mão de técnicas literárias ao construir seu texto. Na perspectiva literária, um texto será tão mais eficaz quanto mais propor novas formas de dizer novas velhas coisas (MARQUES, 2009, p. 19).

Rachel também mostra os desvalidos e menos favorecidos, casos dramáticos, como da menina que nasce com duas cabeças e morre no parto, trágicos, como da criança que morre afogada, revela as agruras das relações sociais e as ilusões, a empregada que se apaixona pelo patrão, tudo, a exemplo do jornalismo, narrado com testemunho de casos particulares que compõem a cena, que desenham o drama, a voz do personagem presente também nas notícias e personagens.

Rachel também mostra os desvalidos e menos favorecidos, casos dramáticos, como da menina que nasce com duas cabeças e morre no parto, trágicos, como da criança que morre afogada, revela as agruras das relações sociais e as ilusões, a empregada que se apaixona pelo patrão, tudo, a exemplo do jornalismo, narrado com testemunho de casos particulares que compõem a cena, que desenham o 
drama, a voz do personagem presente também nas notícias e personagens.

Literatura da brevidade, exercício de recuperação da memória, da história social, da história do simples da vida, este é o todo objeto e assunto da crônica. João do Rio foi quem trouxe para a crônica o caráter literário que não tinha (SÁ, 1987).

O marco inaugural do gênero é o folhetim no século XIX. Cândido (1992) esclarece que o folhetim era uma espécie de artigo de rodapé com comentário sobre política, literatura, artes, as coisas do dia e, assim, aos poucos, foi se transformando, encurtando, tornando-se mais leve, até assumir as feições que consagraram definitivamente o gênero.

Moisés (2004) classifica-a como expressão literária híbrida e múltipla porque nela cabe alegoria, necrológio, entrevista, confissão, monólogo, diálogo. Ele a situa entre a poesia e o conto, e explica: parte de uma visão subjetiva sobre o fato cotidiano. Seu poder está em não ser mera transcrição da realidade, mas na sua capacidade de recriá-la. A crônica, ensinou Moraes (2009), é herdeira dos essays ingleses do século XVIII que a libertaram para o caminho que ela assumiu de ser livre, casual e lírica, considerando ser obrigação do cronista: "ser leve, nunca vago; íntimo, nunca intimista; claro e preciso, nunca pessimista" (MORAES, 2009, p. 53-54).

A crônica se tornou o gênero brasileiro, nas mãos, sobretudo, naqueles anos 1950 e 1960, de Carlos Drummond de Andrade, Vinicius de Moraes, Rubem Braga, Fernando Sabino, dentre outros. A crônica é reconhecida hoje como gênero literário e gênero jornalístico por excelência, está na fronteira entre a literatura e o jornalismo.

A crônica não apenas está entre o jornalismo e a literatura, mas resulta da soma desta e daquela em tudo que lhe é pertinente. Jornalismo, porque seu espaço de publicação é o jornal, e dele herda a precariedade de ser efêmera e de consumo único e diário com a edição do dia, por isso, também, transitória. Toma do texto do jornal a coloquialidade, e do texto da literatura o lirismo. Informar não é a finalidade primeira da crônica. A crônica pode e não pode ter suporte na realidade - o seu exercício é um exercício de liberdade. Sua motivação é o banal, o diário, cotidiano. Tudo pode ser objeto de uma crônica. A crônica é relato sobre o cotidiano, leve, sem rigor, sem método.

O cronista do jornal é repórter e escritor, e, acima de tudo, um grande redator: "não sendo um bom redator (...), ele se limitará a escrever: 'João José Gualberto, vulgo Sorriso, foi preso na madrugada de ontem, no Beco da Felicidade, por ter assaltado a Casa Garson, de onde roubara um lote de discos"' (SÁ, 1987, p. 33), ao passo que o cronista, de um quilate de "Sérgio Porto, consciente das técnicas narrativas e dos recursos da língua portuguesa, reescreverá a notícia assim: 'o Sorriso roubou a música e acabou preso no Beco da Felicidade"' (SÁ, 1987, p. 33).

É o humor, segundo Sá (1987), que confere ao texto da crônica ser no jornalismo uma construção literária: "o jornalista, portanto, não deve simplesmente registrar uma notícia. Cabe a ele explorar o poder das palavras para que o leitor possa vivenciar com emoção semelhante à do repórter, aquilo que está sendo narrado" (SÁ, 1987, p. 33).

Outra não é a forma que Rachel de Queiroz imprimiu no seu trabalho, de tudo um pouco e esta junção de elementos que fazem da crônica um gênero híbrido e próprio, se lê nas crônicas de Rachel de Queiroz publicadas em O Cruzeiro, revista a qual era cronista exclusiva. Da sua colaboração para os jornais Diário de Notícias, O Jornal, Última Hora e Jornal do Comércio, fez o primeiro livro de crônicas $A$ donzela e a moura morta, publicado em 1948.

Dez anos depois, em 1958, o segundo volume de crônicas, 100 crônicas escolhidas, e outros vieram. Trajetória que levou-a a declarar em entrevista: "eu tenho dito que me sinto mais jornalista do que ficcionista. Sempre. Na verdade, minha profissão é essa: jornalista. Há cinquenta e tantos anos que todas as semanas eu escrevo pelo menos um artigo" 
${ }^{2}$ BIBLIOTECA NACIONAL. Página inicial. Disponível em: <https://www.bn.gov. br/>. Acesso em: 23 jul. 2016.

${ }^{3}$ A pesquisadora Letícia Arantes Jury nos forneceu subsídios para pesquisa, apontando que na década de 1950 havia artigos de Rachel de Queiroz a respeito do jornalismo; a partir deste dado, recorremos aos arquivos da Revista O Cruzeiro e encontramos outras crônicas referentes ao jornalismo nas décadas de 1940 e 1960.
(QUEIROZ, 1997, p. 33). São estes artigos, sobretudo, no que tange as reflexões sobre a prática do jornalismo que serão analisados, dentre os textos publicados em O Cruzeiro no período que compreende os anos de 1944 a 1975, quando se encerram as colaborações da cronista com a revista.

\section{Jornalismo na Última Página}

Para esta pesquisa foi feito um levantamento nas edições da revista $O$ Cruzeiro, especificamente na seção Última Página, disponíveis no banco de dados digital da Biblioteca Nacional ${ }^{2}$. Da leitura prévia deste material foram selecionadas dentre os 30 anos de produção oito crônicas, que correspondem a reflexões da escritora sobre a prática do jornalismo. Esta pesquisa nasceu da inquietação acerca dos relatos de jornalistas sobre o seu ofício que trouxessem a partir da sua prática revelações sobre o exercício da atividade (SOBRAL; BULHÕES, 2016).

Desta forma, surgiu a ideia de pesquisar a atividade jornalística a partir do relato dos jornalistas expresso nos seus textos. A escolha recaiu sobre a jornalista (e escritora) Rachel de Queiroz a partir da pesquisa de Jury e Santos (2016), que mencionou existência de crônicas de Rachel que traziam referência ao jornalismo ${ }^{3}$. O acesso a todas as edições de $O$ Cruzeiro nos permitiu ampliar o período para o tempo em que a jornalista colaborou com a revista.

A partir dos títulos e da identificação de elementos-chave das crônicas, chegamos ao seguinte levantamento: Crônica Correios é Telégrafos, publicada em 11 de setembro de 1948; Jornalistas, publicada em 31 de março de 1951; A Ordem dos jornalistas, publicada em 14 de maio 1955; Carta de leitores, publicada em 21 de outubro de 1961; Notícias, publicada em $1^{\circ}$ de abril de 1961; David Nasser e o seu 'velho capitão', publicada em 16 de setembro de 1961; Odylo, jornalista, publicada em 24 de fevereiro de 1962; e Liberdade de imprensa, publicada em 28 de janeiro de 1967.
Assim, a partir desta fonte documental, podemos ressaltar aspectos preliminares acerca das questões pertinentes ao jornalismo tratadas pela autora. A proposta metodológica condizente, portanto, é a exploratória, prescinde do levantamento documental (GIL, 2002) e pesquisa qualitativa aprofundada. A pesquisa qualitativa se torna perfeitamente adequada, pois se detém às interpretações da realidade social. A construção do corpus predispõe uma coleta e seleção dos dados e a análise de conteúdo apresenta suportes metodológicos pertinentes por ser um método de análise de texto desenvolvido pelas ciências sociais empíricas (BAUER; GASKELL, 2002).

Correios e Telégrafos (QUEIROZ, 1948) é o título da Última Página publicado em 11 de setembro de 1948. Neste texto, Rachel de Queiroz vai refletir sobre o acordo do articulista com o veículo de comunicação. Rachel aponta que o trabalho do jornalista tem força contratual, é assinado um contrato, e que envolve uma remuneração pelo serviço. No acordo está disposto que deve o jornalista escrever tantas palavras que vão para uma determinada seção e que este trabalho é contínuo e regular, mas eis que, Rachel de Queiroz apresenta a suposição: o jornalista precisa viajar... não há problema, escreverá, basta acertar com o editor que licenciado pela viagem o jornalista envie a sua colaboração regular. Pois, assegura, haja o que houver, doença, viagem etc., o compromisso admitido não pode ser quebrado porque, além do pacto com o veículo, o jornalista tem um pacto com o leitor a quem só interessa ter disponível a coluna, artigo, crônica.

Rachel considera literalmente que a relação entre os envolvidos, jornalista, veículo, leitor é uma relação de consumo em que o texto é a mercadoria, o público é o consumidor e o veículo é o distribuidor. E o porquê de toda esta ladainha, o caso simples que leva a cronista a estas considerações, é que simplesmente a crônica que enviou do Ceará em 5 de agosto de 1948 foi extraviada pelo correio.

Lamentável o serviço dos correios e telégrafos e com as taxas que se pagam, 
advertea cronista. Então propõe a solução: que todos enviem também as suas queixas que ela fará um dossiê e que será remetido aos responsáveis, certa de que entre o meio milhão de leitores da revista, a tiragem é de 220 mil exemplares ela acrescenta para fazer o cálculo, haverá não só aqueles que devam ter sido prejudicados pelo serviço mas também os responsáveis que devem fazer por onde melhorar a coisa. Ironia e humor marcam assim o texto de Rachel de Queiroz.

Interessante observar a construção argumentativa da jornalista que, com o intuito latente de registrar uma reclamação pública, tangivelmente trouxe elementos para pensar a prática do jornalismo. O jornalismo empresa, tido como negócio, o jornalista prestador de serviço, quando colaborador; e o funcionário, quando repórter. O jornalismo empresa segue o modelo norte-americano e será aquele que se revelará com o discurso da imparcialidade calcado na notícia e na reportagem marcadas pela promessa da objetividade. Um jornalismo que será setorizado em editorias: política, cidades, economia, cultura e esporte, para citar alguns, os mais característicos. Processo que começa no jornalismo impresso nos anos 1950, e que resultou também em uma renovação tecnológica, estilística e estrutural praticando pautas pré-determinadas e utilizando na redação o modelo do lide.

Rachel de Queiroz continuará com as suas reflexões tempo depois, ao publicar na Última Página a crônica Jornalistas de 31 de março de 1951. Certa de que o jornalismo é profissão, dirá mais: é mais que isso, é vocação. E adverte, pode até ser um clichê, mas é a pura verdade, é um emprego como qualquer outro, com horário, salário e tudo mais, mas é também correr riscos, considera Rachel, coisa que outras profissões não comportam. Esse risco é um elemento que ela considera eivado de aventura e que pressupõe a identificação personalíssima do jornalista com o seu trabalho. E que envolve amor, sem ele, considera, o jornalista fracassa. O jornalista tem um quê de ator, porque deve dar tudo de si como o artista no palco, e o que faz sair da alma, e tem a luta, que é própria da essência do jornalismo; também é ser um pouco gladiador, porque se arrisca para poder informar.

Mas foi-se o tempo, considera Rachel de Queiroz, que o articulista era quem despertava as paixões, hoje (refere-se ao tempo em que escrevia a crônica, 1951) são os baluartes da carreira, os repórteres. Que são verdadeiros Dom Quixotes pela bravura com que saem em busca das notícias. Exemplo maior era o seu colega de O Cruzeiro, David Nasser. Porque é o repórter que:

Tem como dom inicial e básico do seu ofício a ubiquidade, que vai onde outro ser humano jamais se atreveu a pisar, que arrisca a vida não por ouro, nem por poder, nem por fanatismo - apenas para colher uma notícia. Que exerce, na vida real, a função que o romancista se arroga em relação aos personagens que inventa - e assim penetra nos pensamentos, escuta conversas que jamais ninguém deveria ouvir, advinha a hora do desastre para lá comparecer com o seu lápis e a sua máquina, está sempre no pior da batalha, no momento crucial do comício, no segredo de todas as coisas secretas (QUEIROZ, 1951, p. 130).

O repórter, para Rachel de Queiroz cronista, era o herói. O exemplo da figura de David Nasser, que será futuramente objeto de outra crônica, o exemplo de baluarte do jornalismo. David Nasser e o seu "velho capitão" será publicada dez anos depois, em 16 de setembro de 1961. Uma homenagem a este cidadão que, segundo a cronista, não quis ser nada mais que repórter. O tom da crônica é o mesmo da passada, o repórter herói que a tudo vence para cumprir a sua missão de informar, sem querer recompensa, apenas pelo simples dever que lhe assiste de informar.

Ser repórter é ofício, vocação e paixão. A ocasião para a crônica era a publi- 
cação do livro de Nasser intitulado Velho capitão. Rachel de Queiroz aproveitará para rememorar seus 25 anos de atividade jornalística e os companheiros de atividade pelos veículos em que passou. E depõe sobre o patrão, o tal velho capitão de Nasser, que nunca interferiu, nos anos todos dela Rachel nos Associados, nas atividades dela como articulista, dizendo assim que exerceu a sua atividade com liberdade de imprensa.

Depois Rachel volta a comentar o livro, e vai traçar mais algumas linhas sobre o que é ofício do repórter e diz que o trunfo de Nasser é ter uma qualidade que não se exige muito dos repórteres: saber escrever. Mas o que mais cabe destacar neste texto da jornalista é a menção ao papel da mulher na atividade. Rachel vai atribuir a atitude democrática do patrão a uma questão de princípios (o patrão no caso é o jornalista Assis Chateaubriand) para dizer que não foi motivo de censura por ser mulher, cuja condição relegaria seus textos a ter somenos importância, por serem as opiniões das mulheres desconsideradas. Mas sim, por senso de justiça.

E assim, denota-se um aspecto que mencionado de forma indireta, era questão do seu tempo, o espaço da mulher na vida pública participando da condição das mulheres no mundo, que era apenas dos homens: "Dir-se- á, talvez, que essa atitude dele viria, principalmente da pouca importância que possam ter as opiniões de uma mulher (...) em meio aos problemas e às discussões dos homens" (QUEIROZ, 1961, p. 146).

Aquelas qualidades que se atribuem ao jornalista exemplar e ao vaticínio da profissão serão também elencadas numa crônica, desta feita publicada na edição de 24 de fevereiro de 1962. Rachel de Queiroz falará do jornalista Odylo Costa Filho em Odylo, jornalista. Eleito por unanimidade na roda de amigos como o jornalista brasileiro mais completo e atuante, segundo Rachel de Queiroz, reúne todas as qualidades essenciais dos grandes articulistas e dos fabulosos repórteres (os adjetivos são dela) e isso implica ter cultura, bom gosto e inteli- gência, que o torna capaz de transformar um fato do cotidiano em notícia:

Como articulista, possui o talento específico de transformar o fato cotidiano em assunto jornalístico, de fazer da controvérsia uma arte e do debate uma ciência, de esgotar qualquer tema sem cais nos dois escolhos antípodas que ameaçam o colunista: ou dar impressão de superficialidade e de improviso, ou cair no pecado oposto - a estreiteza especializada (QUEIROZ, 1962, p. 138).

E o repórter: "é seu aquele faro singular que colhe a boa notícia no ar, antes dos outros, que sabe destilar do boato a informação autêntica, que desencava o fato vivo no chão onde se oculta, que na meia palavra de um prócer pega o segredo das intrigas mais enredadas" (QUEIROZ, 1962, p. 138).

E traça um vaticínio do seu tempo refletindo sobre o futuro da profissão. A competição com um novo tipo de jornalista que surge nas redações, aquele preocupado com o glamour e a vaidade decorrente da profissão que, ela afirma, mesmo tendo consciência que o jornalismo é uma indústria (posição que verificamos em artigo anterior), a matéria não pode ser produzida em escala e exige estas qualidades e talentos que ela defende como excelência do bom jornalista ou jornalista ideal.

Interessante que Rachel de Queiroz não considera conflituosa essa composição entre o jornalismo-empresa e um fazer artesanal por parte do jornalista que, antes de tudo, deve ser um intelectual. Os demais artigos em que trata da profissão, Rachel de Queiroz dedicará uma Última Página a ordem dos jornalistas; outra a importância da carta dos leitores; trará reflexões sobre o noticiário; e em outra sobre o papel de informar e discutirá mais uma vez a liberdade de imprensa.

A ordem dos jornalistas foi título da crônica do dia 14 maio de 1955. Rachel de Queiroz abordou a campanha que 
surgia na imprensa para criação de uma ordem dos jornalistas, similar a ordem dos advogados. E passava a defender o bem maior dos jornalistas: a liberdade de imprensa e o respeito à ética (também jornalística) fixando que o primado do jornalismo não é o furo a qualquer preço, mas a legitimidade e a verdade que a notícia apresenta. Entendia que o jornalismo estava mal visto, pelo desrespeito que alguns profissionais praticam no exercício da profissão. Um jornalismo que desrespeitava, com acusações infundadas, publicidade enganosa sobre gente inocente, praticando injustiças até contra autoridades. A cronista alegava que o remédio, infelizmente, era a justiça, apesar de ser tardia e morosa, e que a legislação era complacente, defendendo uma ordem e ética para os jornalistas. Ela acreditava que apenas eles mesmos, os profissionais, podiam e deviam agir com zelo e respeito e não seriam leis mais severas que coibiriam abusos.

Outro ponto defensável ao trabalho do jornalista são as cartas dos leitores. Rachel de Queiroz defende em Carta de leitores, de 21 de outubro de 1961, o papel das cartas como termômetro para atividade do jornalista, é quando os leitores desafogam tudo que devem, porque os tons das cartas são: desabafos, reclamações, sugestões, convites, elogios e até pedidos. E são importantes porque sem elas, o jornalista perde o prumo, fica "sem saber direito o que está fazendo". E desculpa-se, é impossível, pela quantidade, responder a todas as cartas de tom mais pessoal, que são inúmeras. E que o diálogo entre o cronista e o leitor só é possível na coluna. E finda a coluna completando a função social do jornalismo: publica um apelo de um filho que tendo sua mãe desaparecida há muito, pede que quem souber do seu paradeiro que entre em contato.

Notícias aparece na edição de primeiro de abril de 1961, e o assunto é manipulação. A concentração midiática, denuncia a cronista, tende à manipula- ção. Os olhos se voltam para a imprensa internacional. A jornalista questiona: quanto dos atritos entre Estados Unidos e Cuba não é refrega da imprensa? E o Brasil, então, Rachel de Queiroz avisa: é presa fácil do correspondente estrangeiro que recebido (ela alega) com pompas de chefe de estado sai daqui escrevendo o que bem quer, seja lisonjeiro ou não. $\mathrm{E}$ desfazer notícia mal feita é trabalho perdido, um bom noticiário nem sempre é capaz de recuperar o estrago.

A última reflexão de Rachel de Queiroz sobre a imprensa em O Cruzeiro aparece anos depois e novamente com o assunto da liberdade de imprensa, tanto que é o título da crônica publicada em 28 de janeiro de 1967; escreve a cronista sobre a censura velada nos Estados Unidos: "e vem eles, agora, do alto do seu dinheiro grosso, nos dar lição de liberdade de imprensa! Ora, não nos façam rir" (QUEIROZ, 1967, p. 126).

\section{Considerações finais}

Após apresentar a trajetória de Rachel de Queiroz como jornalista, enfatizando sua contribuição de mais de 30 anos na revista $O$ Cruzeiro, foram elencadas as análises de oito crônicas, publicadas entre 1948 e 1967, nas quais a autora versou sobre o fazer jornalístico.

Pudemos perceber, nas crônicas destacadas, que a jornalista era crítica em relação à profissão, tanto no que tange as práticas específicas dos profissionais da mídia, quanto à visão da sociedade acerca do ofício. Também são temáticas recorrentes a liberdade de imprensa e aspectos da política brasileira do momento.

Por fim, destacamos que a contribuição material e simbólica de Rachel de Queiroz ao Jornalismo não se resume às crônicas elaboradas para a revista $\mathrm{O} C r u$ zeiro, pois a cronista continuou a escrever para outros veículos com a mesma verve, conforme abordado em outras publicações (SOBRAL; BULHÕES, 2017). 


\section{Referências}

BAUER, M; GASKELL, G. (Orgs.). Pesquisa qualitativa com textos, imagem e som: um manual prático. Petrópolis: Vozes, 2002.

BIBLIOTECA NACIONAL. Página inicial. Disponível em: <https://www.bn.gov. br/>. Acesso em: 23 jul. 2016.

CÂNDIDO, Antônio. A vida ao rés do chão. In: CÂNDIDO, Antônio. A crônica: o gênero, sua fixação e transformações no Brasil. Campinas: Editora da Unicamp; Rio de Janeiro: Fundação Casa Rui Barbosa, 1992.

GIL, Antônio Carlos. Como elaborar projetos de pesquisa. 4. ed. São Paulo: Atlas, 2002.

JURY, Letícia Arantes; SANTOS, Goiamérico. A trajetória da "revista contemporânea dos arranha-céus": um estudo sobre O Cruzeiro na década de 50. In: Anais do XVIII Congresso de Ciências da Comunicação na Região Centro-Oeste, Goiânia, 2016.

MARQUES, Fabrício. Jornalismo e literatura: modos de dizer. Conexão, v. 8, n. 16, Caxias do Sul, jul. a dez. 2009.

MENDES, Fernanda Coelho. A "fiadora do governo": as crônicas de Rachel de Queiroz na revista O Cruzeiro (1960-1975). (Dissertação de mestrado), Unirio, 2017.

MOISÉS, Massaud. Dicionários de termos literários. 12. ed. São Paulo: Cultrix, 2004.

MORAES, Vinicius de. O exercício da crônica. In: MORAES, Vinicius de. Para uma menina com uma flor. São Paulo: Companhia das Letras, 2009.

MORAIS, Fernando. Chatô: o rei do Brasil. A vida de Assis Chateaubriand. São Paulo: Companhia das Letras, 1994.

QUEIROZ, Rachel de. Cadernos de Literatura Brasileira, no 4. São Paulo: Instituto Moreira Salles, 1997.

QUEIROZ, Rachel de. Um alpendre, uma rede, um açude. 8. ed. Rio de Janeiro: José Olympio, 2006.

QUEIROZ, Rachel de. Correios \& telégrafos. Revista O Cruzeiro. Publicado em: 11 set.1948. Disponível em: <http://memoria.bn.br>. Acesso em 28 jun. 2016.

QUEIROZ, Rachel de. Jornalistas. Revista O Cruzeiro. Publicado em: 31 mar. 1951. Disponível em: <http://memoria.bn.br>. Acesso em 28 jun. 2016.

QUEIROZ, Rachel de. A Ordem dos jornalistas. Revista O Cruzeiro. Publicado em: 14 maio 1951. Disponível em: <http://memoria.bn.br>. Acesso em 28 jun. 2016.

QUEIROZ, Rachel de. Carta de leitores. Revista O Cruzeiro. Publicado em: 21 out. 
1961. Disponível em: <http://memoria.bn.br>. Acesso em 28 jun. 2016.

QUEIROZ, Rachel de. Notícias. Revista O Cruzeiro. Publicado em: 01 abr. 1961. Disponível em: <http://memoria.bn.br>. Acesso em 28 jun. 2016.

QUEIROZ, Rachel de. David Nasser e o seu “velho capitão”. Revista O Cruzeiro. Publicado em: 16 set. 1961. Disponível em: <http://memoria.bn.br>. Acesso em 28 jun. 2016.

QUEIROZ, Rachel de. Odylo, jornalista. Revista O Cruzeiro. Publicado em: 24 fev. 1962. Disponível em: <http://memoria.bn.br>. Acesso em 28 jun. 2016.

QUEIROZ, Rachel de. Liberdade de imprensa. Revista O Cruzeiro. Publicado em: 28 jan. 1967. Disponível em: <http://memoria.bn.br>. Acesso em 28 jun. 2016.

SÁ, Jorge de. A crônica. São Paulo: Ática, 1987.

SOBRAL, Gustavo; BULHÕES, Juliana. Propostas para o estudo das biografias e autobiografias de jornalistas brasileiros. In: Anais do XVIII Congresso de Ciências da Comunicação na Região Nordeste, Caruaru, 2016.

SOBRAL, Gustavo Leite; BULHÕES, Juliana. A faceta jornalística de Rachel de Queiroz: perspectivas biográficas. Temática - Revista eletrônica de publicação mensal, v. 1, p. 15- 28, 2017. 